\title{
Pengaruh Perbedaan Konsentrasi Surfaktan Non Ionik terhadap Karaktersitik Niosom Pterostilben
}

\author{
Kartika Zulfa ${ }^{1}$, Ferri Widodo ${ }^{1}$, Oktavia Eka Puspita ${ }^{1}$ * \\ ${ }^{1}$ Jurusan Farmasi, Fakultas Kedokteran, Universitas Brawijaya, Malang, Indonesia
}

\section{INFO ARTIKEL}

Sejarah artikel:

Penerimaan

naskah: 12 Juli

2019

Penerimaan

naskah revisi: 23

Oktober 2020

Disetujui untuk

dipublikasikan: 30

November 2020

\section{Kata kunci :}

Evaluasi, Span

60,Span

80,Ukuranpartik

el

\section{A B S T R A K}

Radisi sinar UV yang berlebih dapat menyebabkan kerusakan kulit hingga melanoma, khususnya sinar UVB. Efek kronis dari paparan sinar UVB yang berlebih dapat menginduksi mutasi gen, karena langsung menyebabkan kerusakan pada DNA seluler dengan memproduksi ROS di epidermis, dermis dan sel epitelium kulit. Penggunaan tabir surya sangat diperlukan untuk mencegah terjadinya hal tersebut. Tabir surya yang mengandung antioksidan sangat direkomendasikan untuk menangkal radikal bebas dari sinar UVB. Pterostilben merupakan salah satu senyawa fenolik, yang memiliki aktivitas farmokologi antioksidan dan UV filter menjadi salah satu senyawa yang direkomendasikan untuk komponen tabir surya. Untuk meningkatkan efek farmakologi pterostilben pada penggunaan topikal, pterostilben perlu diformulasikan sistem penghantaran. Niosom merupakan vesikel surfaktan non ionik menjadi salah satu sistem pembawa amfifilik yang dapat membawa bahan aktif bersifat hidrofobik seperti pterostilben, diharapkan mampu meningkatkan efek farmakologi dengan meningkatkan penetrasi pterostilben ke kulit. Pembuatan niosom pterostilben menggunakan surfakan non ionik (span 80 dan span 60) dengan metode hidrasi lapis tipis. Tujuan dari pengembangan formulasi niosom pterostilben adalah untuk melihat pengaruh konsentrasi surfaktan non ionik (span 80 dan span 60), yaitu 2, 4, dan $6 \mathrm{~g}$ terhadap ukuran partikel yang dihasilkan dan menentukan formulasi optimum. Hasil uji karakteristik ukuran partikel niosom pterostilben dianalisis statistik menggunakan One-Way ANOVA dengan $p<0,05$. Hasil dari penelitian ini menunjukkan bahwa ukuran niosom pterostilben semakin kecil dengan peningkatan konsentrasi span 60. Berdasarkan hasil tersebut, didapatkan formulasi optimum niosom pterostilben yaitu pada penggunaan span 60 dengan konsentrasi $6 \mathrm{~g}$.

\section{Effect of Non Ionic Surfactant Concentration on Pterostilbene Niosome Characteristics}

\section{Keywords:}

Evaluation, Span 60, Span

80, Particle size

\begin{abstract}
A B S T R A C T
Excessive radiation from UV light can cause skin damage to melanoma, especially UVB rays. Chronic effects from exposure of excessive UVB rays can induce gene mutations because the exposure of excessive UVB rays directly causes damage to cellular DNA by producing ROS in the epidermis, dermis, and skin epithelium cells. The use of sunscreen is very necessary to prevent skin damage. Sunscreen containing antioxidants are highly recommended to protect the skin from free radicals UVB rays. Pterostilbene is one of the phenolic compounds, which has the pharmacological activity of antioxidants and UV filters to be one of the recommended compounds for sunscreen components. A good delivery system is needed to be formulated to improve the pharmacological effects of pterostilbene on topical use. Niosomes are non-ionic surfactant vesicles which are one of the amphiphilic carrier systems which can carry hydrophobic active ingredients such as pterostilbene, which are expected to increase the pharmacological effect by increasing the penetration of pterostilbene into the skin. Pterostilbene niosome using non-ionic surfactant (span 80 and span 60) by thin layer hydration method. The research aimed to examine the effect of surfactant concentration (span 80 and span 60) 2, 4, and $6 \mathrm{~g}$ toward the characterization of niosome pterostilbene and determine the optimum formulation by particle size. The results of the study showed that the particle size was smaller with an increase in span concentration. Based on these results, the optimum formulation of pterostilbene niosomes is obtained using span 60 with a concentration of $6 \mathrm{~g}$.
\end{abstract}




\section{Pendahuluan}

Kulit adalah organ terbesar pada tubuh dan bertugas sebagai penghalang pertama terhadap sinar radiasi UV, pathogen, tekanan mekanik, dan racun kimiawi. Hal ini memungkinkan kulit dapat mengalami kerusakan yang berujung pada penyakit kulit sampai melanoma. Sinar UVB diketahui penyebab paling poten dari kerusakan secara akut maupun kronis, karena dapat menginduksi terjadinya mutasi gen yang disebabkan adanya kerusakan DNA karena sinar UVB. ${ }^{1}$

Indonesia adalah negara yang terletak di sepanjang garis khatulistiwa, hal ini berarti paparan sinar UV cukup tinggi sepanjang tahun. Menurut Riskesdas ${ }^{2}$ tahun 2007, kanker kulit menempati urutan ketiga dari keseluruhan jenis kanker di Indonesia. Mengingat bahaya dari radiasi sinar UV, khususnya sinar UVB diperlukan perlindungan untuk mencegah terjadinya kerusakan kulit yang dapat berujung melanoma. Pada saat ini penggunaan tabir surya dengan bahan aktif senyawa antioksidan menjadi pilihan solusi untuk menangkal radikal bebas dari sinar $\mathrm{UVB}^{3}$

Pterostilben pertama kali ditemukan pada blueberries dan batang Pterocarpus marsupium, merupakan kelas senyawa polifenol. Pterostilben merupakan analog dari senyawa resveratrol, dimana memiliki aktivitas antioksidan, antiinflamasi, dan antikarsinogen. Aktivitas pterotilben adalah dengan menangkap radikal bebas, menekan produksi reactive oxygen species (ROS) dan menstimulasi biosintesis antioksidan endogen. Pterostilben juga memiliki aktivitas sebagai UV filter karena memiliki struktur polifenol yang dapat mengabsorbsi radian sinar $\mathrm{UV}^{4}$

Pemberian rute topikal menjadi pilihan untuk pterostilben yang mempunyai aktivitas menangkap radiasi sinar UVB. Sediaan yang ditujukan untuk pemberian secara topikal diharapkan memiliki kemampuan adhesi yang baik pada permukaan kulit, penetrasi ke kulit, dan efek yang terlokalisasi pada lapisan kulit tertentu. Selain itu, pterostilben juga memiliki karakteristik tidak stabil terhadap cahaya dan udara, karena gugus hidroksil fenolik pada pterostilben akan mudah teroksidasi, sehingga memungkinkan terjadinya penurunan aktivitas farmakologi secara signifikan. ${ }^{21}$ Oleh karena itu, diperlukan modifikasi sistem penghantaran yang sesuai untuk dapat meningkatkan kelarutan dan stabilitas dari pterostilben, sehingga dapat meningkatkan efek farmokologi dari pterostilben. Salah satu hal yang mempengaruhi adalah ukuran partikel sediaan itu sendiri. Semakin kecil ukuran partikel maka semakin luas permukaan, sehingga dapat meningkatkan kemampuan penetrasi ke kulit dan meningkatkan efek obat dengan membuat obat bereaksi pada lokasi administrasi, maka diperlukan sistem penghantaran yang dapat membantu pterostilben dalam melindungi dan mengobati kulit dari kerusakan akibat paparan radiasi sinar UV-B. ${ }^{14}$

Konsep sistem penghantaran terkontrol dan tertarget adalah merancang suatu senyawa aktif untuk dapat terpusat pada jaringan dengan mengurangi konsentrasi obat yang tersisa di jaringan. Sehingga diharapkan obat tertarget di lokasi pemberian. Niosom merupakan salah satu sistem pembawa berbentuk vesikel yang terdiri dari surfaktan non ionik. Niosom (Non ionic surfactant vesicles) diperoleh dari hidrasi memiliki struktur mikroskopik lamellar dengan kombinasi surfaktan non ionik, kolesterol, dan bahan tambahan lain. Niosom memiliki struktur bilayer yang berisfat ampifilik, sehingga dapat sebagai sistem penghantaran untuk obat hidrofilik maupun hidrofobik, seperti pterostilben yang memiliki sifat lebih hidrofobik. Sistem penghantaran menggunakan niosom merupakan salah satu pendekatan untuk mencapai aktivitas obat yang poten dapat tertarget di lapisan kulit tertentu seperti epidermis dan dermis. ${ }^{5}$

Stabilitas niosom dipengaruhi oleh beberapa faktor, salah satunya adalah jenis surfaktan non ionik yang digunakan dan konsentrasinya. Surfaktan non ionik pada niosom berperan penting dalam pembentukan nosom, ini akan membentuk vesikel bilayer rapat di dalam media air, hal ini yang membuat niosom memiliki sifat ampifilik. Gugus hidrofobik akan tetap terjaga dari pelarut air, sedangkan gugus kepala hidrofilik yang akan kontak langsung dengan pelarut air. Surfaktan non ionik yang digunakan dalam pembuatan niosom harus bersifat biodegradable, biokompatibel dan tidak mengakibatkan aktivitas imunogenik. Surfaktan yang kompatibel dapat membentuk niosom memiliki nilai HLB pada rentang $4-8$ dan harus bersifat biodegradable serta tidak menimbulkan aktivitas imunogenik. ${ }^{6}$

Dalam penelitian ini surfaktan non ionik yang digunakan, dipilih berdasarkan nilai HLB yang sesuai untuk pembuatan niosom. Contoh surfaktan yang memiliki nilai HLB dalam rentang tersebut adalah span 60 dan span 80 , berturut-turut yaitu, 4,7 dan 4,3. Surfaktan yang digunakan untuk pembuatan niosom dalam penelitian ini akan dilakukan variasi konsentrasi untuk melihat pengaruhnya terhadap karakteristik niosom pterostilben yang meliputi organoleptis, $\mathrm{pH}$, ukuran partikel, indeks polidispersitas, dan potensial zeta. Variasi jenis dan konsentrasi dari surfaktan non ionik dapat mempengaruhi karakteristik niosom yang dihasilkan, salah satunya adalah ukuran vesikel niosom. Ukuran vesikel niosom yang lebih kecil ditunjukkan pada penggunaan surfaktan dengan nilai HLB lebih kecil karena terjadi peningkatan hidrofobisitas dan konsentrasi span yang lebih tinggi, hal ini kemungkinan dikarenakan surfaktan lebih memudahkan

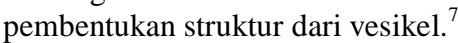

Pengembangan formulasi niosom pterostilben bertujuan untuk melihat pengaruh perbedaan surfaktan non ionik (span 60 dan span 80) dan konsentrasinya terhadap karakteristik ukuran partikel yang dihasilkan. Konsentrasi surfaktan non ionik yang digunakan dalam penelitian ini, yaitu F1, F2, dan F3 berturut-turut 2, 4, dan 6 g dengan konsentrasi lipid yang tetap yaitu kolesterol $500 \mathrm{mg}$ serta soya lecithin $2 \mathrm{~g}$. Pengujian potensial zeta, indeks polidispersitas dan difusi in vitro juga dilakukan dalam penelitian ini.

\section{Metode \\ Bahan}

Bahan yang digunakan dalam pembuatan niosom pterostilben adalah pterostilben (ChromaDex ${ }^{\circledR}$ ) sebagai bahan aktif, span 60 dan span 80 yang diperoleh dari C.V. Duta Jaya, kolesterol yang diperoleh dari C.V. Gamma Scientific Lab, dan soya lecithin (Sonic Biochem). Serta pelarut yang digunakan adalah kloroform (Smart Lab) dan larutan buffer fosfat $\mathrm{pH} 7,4$.

\section{Alat}

Alat yang digunakan dalam pembuatanniosom pterostilben adalah neraca analitik (OHAUS PIONEER ${ }^{\circledR}$ ), Rotary evaporator (IKA ${ }^{\circledR}$ RV 10 basic), pompa vakum (Vacuubrand $^{\circledR}$ ), ultra turrax $\left(\right.$ IKA $^{\circledR} \mathrm{T} 25$ digitl), sonikator $\left(\right.$ Sonica $\left.{ }^{\circledR}\right)$, dan $\mathrm{pH}$ meter $\left(\mathrm{SCHOTT}^{\circledR}\right)$. Alat yang 
digunakan dalam pengujian karakteristik niosom pterostilben adalah particle size analyzer (Malvern Zetasizer Nano Series ${ }^{\circledR}$ ) dan spektrofotometri UV-Vis (Shimadzu UV-1800 ${ }^{\circledR}$ ).

\section{Prosedur Penelitian}

\section{Pembuatan Niosom Ptersotilben}

Niosom pterostilben diformulasikan dengan metode hidrasi lapis tipis. Surfaktan non ionik, kolesterol, soya lecithin dan pterostilben masing-masing ditimbang sesuai dengan Tabel 1, lalu dilarutkan ke dalam $\pm 10 \mathrm{~mL}$ kloroform. Kemudian campuran lipid dievaporasi menggunakan rotary evaporator pada suhu $60^{\circ} \mathrm{C}$, dengan kecepatan $150 \mathrm{rpm}$ dan kondisi vakum sampai terbentuk lapis tipis pada dinding labu alas bulat. Lapis tipis dihidrasi setelah didiamkan semalaman menggunakan larutan buffer fosfat $\mathrm{pH} 7,4$ sebanyak $50 \mathrm{~mL}$ dengan rotary evaporator tanpa vakum selama 1 jam pada suhu $60^{\circ} \mathrm{C}$, dengan kecepatan $150 \mathrm{rpm}$. Setelah mencapai suhu ruang, suspensi niosom pterostilben diperkecil ukurannya dengan ultra turrax selama 5 menit dengan kecepatan $8000 \mathrm{rpm}$ kemudian disonikasi selama 5 menit pada suhu ruang. Niosom pterostilben kemudian disimpan dalam lemari pendingin pada suhu $4^{\circ} \mathrm{C}$ untuk selanjutnya dilakukan uji.

Tabel 1. Komposisi Formulasi Niosom Pterostilben

\begin{tabular}{ccccc} 
Formula & $\begin{array}{c}\text { Pterostilben } \\
(\mathrm{g})\end{array}$ & $\begin{array}{c}\text { Surfaktan } \\
\text { non ionik } \\
(\mathrm{g})\end{array}$ & $\begin{array}{c}\text { Kolesterol } \\
(\mathrm{g})\end{array}$ & $\begin{array}{c}\text { Soya } \\
\text { lecithin }(\mathrm{g})\end{array}$ \\
\hline F1 & 0,14 & 2 & 0,5 & 2 \\
\hline F2 & 0,14 & 4 & 0,5 & 2 \\
\hline F3 & 0,14 & 6 & 0,5 & 2 \\
\hline K1 & - & 2 & 0,5 & 2 \\
\hline K2 & - & 4 & 0,5 & 2 \\
\hline K3 & - & 6 & 0,5 & 2
\end{tabular}

Keterangan: $\mathrm{K}=$ tanpa pterostilben, $\mathrm{F}=$ dengan pterostilben, $\mathrm{F} 1=$ konsentrasi surfaktan non ionik $2 \mathrm{~g}, \mathrm{~F} 2=$ konsentrasi surfaktan non ionik 4 $\mathrm{g}, \mathrm{F} 3=$ konsentrasi surfaktan non ionik $6 \mathrm{~g}$.

\section{KARAKTERISASI NIOSOM PTEROSTILBEN Organoleptis}

Uji organoleptis dilakukan untuk mengetahui kondisi fisik dari niosom pterostilben yang diamati secara visual. Uji ini meliputi bentuk, warna, dan bau.

\section{pH}

$\mathrm{pH}$ niosom pterostilben diukur menggunakan $\mathrm{pH}$ meter yang sudah dinetralkan dengan aquadest dan larutan buffer standard $\mathrm{pH} 7$.

\section{Ukuran Partikel}

Analisis ukuran partikel dilakukan menggunakan alat particle size analyser dengan metode dynamic light scattering. $100 \mu \mathrm{L}$ sampel dincerkan ke dalam $4 \mathrm{~mL}$ larutan buffer fosfat $\mathrm{pH}$ 7,4. Pengukuran dilakukan sebanyak tiga kali repilkasi. ${ }^{19}$

\section{Indeks Polidispersitas}

Pengukuran indeks polidispersitas dilakukan untuk mengetahui distribusi ukuran partikel niosom pterostilben. Pengukuran menggunakan alat particle size analyser dengan metode dynamic light scattering. $100 \mu \mathrm{L}$ sampel dincerkan ke dalam $4 \mathrm{~mL}$ larutan buffer fosfat $\mathrm{pH} 7,4$. Pengukuran dilakukan sebanyak tiga kali repilkasi. ${ }^{19}$

\section{Potensial Zeta}

Analisis potensial zeta dilakukan men Analisis ukuran partikel dilakukan menggunakan alat particle size analyser dengan metode dynamic light scattering. $100 \mu \mathrm{L}$ sampel dincerkan ke dalam $4 \mathrm{~mL}$ larutan buffer fosfat $\mathrm{pH} 7,4$. Pengukuran dilakukan sebanyak tiga kali repilkasi. ${ }^{19}$

\section{Uji Difusi in vitro}

Uji difusi in vitro ini dilakukan untuk mengetahui kemampuan difusi niosom pterostilben. Uji difusi in vitro ini dilakukan menggunakan metode Franz Diffusion Cell Type. Sampel niosom sebanyak 2,5 mL $(2,8 \mathrm{mg} / \mathrm{mL})$ diletakkan pada membran antara kompartemen donor dan reseptor yang mengandung larutan buffer fosfat $\mathrm{pH} 7,4$. Selama pengujian, suhu dijaga tetap pada $37^{\circ} \mathrm{C} \pm 5{ }^{\circ} \mathrm{C}$ dengan kecepatan $200 \mathrm{rpm}$. Sampel diambil sebanyak 1 mL pada interval waktu 15,30, 45, 60, 90, dan 120 menit pada kompartemen reseptor. Media segera digantikan dengan larutan buffer fosfat $\mathrm{pH}$ 7,4 sesuai dengan volume yang diambil. Kemudian sampel diencerkan dengan larutan buffer fosfat $\mathrm{pH}$ 7,4 dan dianalisis menggunakan spektrofotometri UV-Vis pada $\lambda$ maksimal $345 \mathrm{~nm}^{27}$

\section{Hasil dan Diskusi}

Pterostilben dalam penelitian ini diformulasikan untuk menghasilkan niosom pterostilben. Sistem penghantaran niosom diharapkan dapat meningkatkan efek pterostilben dengan mengakomodasi konsentrasi obat lebih baik pada lokasi administrasi, kemampuan adhesi dan penetrasi pterostilben ke kulit. Niosom dapat meningkatkan penetrasi pterostilben melewati kulit dengan cara mengurangi transepidermal water loss sehingga dapat mempengaruhi struktur stratum korneum yang kaku dan padat. Penggunaan nanovesikel menunjukkan permeabilitas dan retensi obat ke kulit lebih baik daripada sediaan yang tidak menggunakan nanovesikel ${ }^{10}$, dalam penelitian yang memformulasikan sediaan topikal gel niosom untuk terapi psoriasis menunjukkan bahwa obat mampu berdifusi melewati kulit dan terdeposisi dikulit lebih baik dibandingkan dengan gel biasa, sehingga dapat meningkatkan efek terapi. Niosom juga dapat melindungi bahan aktif yang kurang stabil secara kimia, seperti fotodegradasi. ${ }^{20}$ Pada penelitian ini, pterostilben dapat dengan mudah teroksidasi jika terpapar cahaya. Sehingga formulasi niosom pterostilben dapat diharapkan dapat melindungi pterostilben dari oksidasi karena cahaya dan dapat meningkatkan efek terapi dari pterostilben. ${ }^{21}$

Niosom pterostilben diformulasikan dengan metode hidrasi lapis tipis. Metode hidrasi lapis tipis merupakan metode yang paling sering digunakan dalam pembuatan nanovesikel, dikarenakan metode ini simple dan praktis serta mampu menghasilkan partikel kecil yang seragam. Pada 
metode hidrasi lapis tipis terjadi pembentukan lapis tipis dan proses hidrasi sehingga terbentuk vesikel. Pterostilben, span, kolesterol, dan soya lecithin dilarutkan dalam pelarut organik yang kemudian dievaporasi untuk menghilangkan pelarut organik sampai membetuk lapis tipis di dinding alas bulat. Proses hidrasi merupakan salah satu titik kritis pembentukan vesikel pada metode ini. Penambahan fase aqueous pada proses hidrasi ke dalam lapis tipis menyebabkan pengembangan bilayer dari campuran lipid dan secara bersamaan akan membentuk vesikel karena adanya interaksi fase air dengan gugus polar molekul surfaktan. Interaksi antara air dan bilayer, akan menghasilkan struktur vesikel yang akan memisah dengan sendirinya. ${ }^{11}$ Suhu hidrasi mempegaruhi bentuk dan ukuran partikel niosom. Dalam pembuatan niosom, suhu yang digunakan biasanya harus di atas suhu transisis fase gel likuid dari surfaktan yang digunakan. $^{22}$ Setelah hidrasi, dilanjutkan dengan pengecilan ukuran menggunakan ultra turrax dan sonikator. Vesikel yang terbentuk setelah proses pengecilan menunujukkan ukuran yang lebih kecil dan distribusi ukuran partikel yang lebih homogen. $^{23}$

Pada preparasi niosom pterostilben menggunakan span 80 sebagai surfaktan non ionik, penelitian tidak dilanjutkan karena dalam proses pembuatan niosom menggunakan span 80 tidak terbentuk lapis tipis yang menempel pada dinding labu alas bulat dan tidak terjadi pembentukan vesikel saat proses hidrasi. Hal ini dapat disebabkan oleh beberapa faktor dari karkateristik surfaktan, yaitu nilai HLB dan suhu transisi fase gel-likuid. Tidak terbentuknya lapis tipis pada dinding labu alas bulat, dapat disebabkan dari suhu transisi fase gellikuid span 80 yang sangat rendah, yaitu $-12{ }^{\circ} \mathrm{C}$. Berdasarkan literatur, suhu transisi fase gel-likuid surfaktan non ionik dapat mempengaruhi proses pembentukan niosom. Suhu transisi fase gel-likuid yang rendah tidak dapat membentuk fase gel pada suhu ruang tanpa kolesterol dengan konsentrasi tinggi. ${ }^{25}$ Pada proses hidrasi, didapatkan bahwa campuran lipid yang terdiri dari span 80 dan kolesterol memisah dengan media hidrasi dan tidak membentuk vesikel. Tidak terbentuknya vesikel niosom pada penggunaan span 80 mungkin disebabkan oleh beberapa faktor, yaitu tidak terbentuknya struktur lipid bilayer karena kurangnya bahan pembentuk dinding bilayer niosom dan nilai HLB span 80 yang lebih kecil. Oleh karena itu, pada pembuatan niosom menggunakan span 60 ditambahkan lesitin yang diharapkan dapat meningkatkan stabilitas fisik niosom pterostilben. Lesitin dalam komponen niosom dapat meningkatkan kerapatan struktur dinding bilayer, sehingga dapat mencegah terjadinya kebocoran pada vesikel. $^{26}$ Nilai HLB span 80 yang lebih kecil dapat menghasilkan ukuran partikel yang lebih kecil, namun dapat meningkatkan kebocoran atau rusaknya vesikel. ${ }^{7}$

\section{KARAKTERISASI NIOSOM PTEROSTILBEN Organoleptis}

Hasil pengamatan secara visual niosom pterostilben ditunjukkan pada Tabel 2. Niosom pterostilben yang dihasilkan memiliki bentuk, warna, dan bau yang sama pada semua kelompok. Niosom pterostilben diformulasikan menggunakan metode hidrasi lapis tipis yang dikombinasi dengan proses pengecilan ukuran menggunakan ultra turrax dan sonikator. Metode hidrasi lapis tipis dapat menghasilkan niosom multilamelar serta ukuran partikel yang kecil dan seragam. ${ }^{11}$ Niosom pterostilben yang dihasilkan menunjukkan organoleptis yang seragam pada semua kelompok, yaitu berbentuk cair, berwarna kuning pucat dan memiliki bau khas soya lecithin. Hal ini kemungkinan dikarenakan komponen niosom yang digunakan pada penelitian tidak memiliki warna yang kuat. Niosom pterostilben kemudian di uji $\mathrm{pH}$, ukuran partikel, PDI, potensial zeta, dan uji difusi.

Tabel 2. Hasil Evaluasi Organoleptis Niosom Pterostilben

\begin{tabular}{llll}
\hline Kelompok & \multicolumn{2}{c}{ Organoleptis } \\
\cline { 2 - 4 } & Bentuk & Warna & Bau \\
\hline K1 & Cair & Kuning pucat & Khas soya lecithin \\
\hline K2 & Cair & Kuning pucat & Khas soya lecithin \\
\hline K3 & Cair & Kuning pucat & Khas soya lecithin \\
\hline F1 & Cair & Kuning pucat & Khas soya lecithin \\
\hline F2 & Cair & Kuning pucat & Khas soya lecithin \\
\hline F3 & Cair & Kuning pucat & Khas soya lecithin \\
\hline
\end{tabular}

Keterangan: $\mathrm{K}=$ tanpa pterostilben, $\mathrm{F}=$ dengan pterostilben, $\mathrm{F} 1=$ konsentrasi Span 60 2, F2= konsentrasi Span 604 g, F3= konsentrasi Span $606 \mathrm{~g}$.

\section{Ukuran Partikel}

Hasil uji ukuran partikel niosom pterostilben (Tabel 3) menunjukkan bahwa ukuran partikel semakin kecil dengan meningkatnya konsentrasi span 60 pada kelompok formula maupun kontrol $(p<0,05)$. Hal ini menjelaskan bahwa pembentukan vesikel yang lebih mudah karena dapat mencapai titik misel kritis dengan cepat dan/atau kemampuan surfaktan dalam mengakomodasi pembentuk struktur vesikel lebih baik pada saat penggunaan surfaktan dengan konsentrasi relatif lebih tinggi. ${ }^{7}$ Hasil ukuran partikel dari terkecil berturutturut adalah $\mathrm{F} 3<\mathrm{F} 2<\mathrm{F} 1$ untuk kelompok formula dan $\mathrm{K} 3<\mathrm{K} 2<\mathrm{K} 1$ untuk kelompok kontrol. Ukuran partikel niosom pterostilben berada pada rentang $235-310 \mathrm{~nm}$. Nilai tersebut memenuhi syarat ukuran partikel untuk dapat bisa berpenetrasi ke lapisan kulit yang lebih dalam seperti epidermal dan dermal. Dimana partikel dengan ukuran > $600 \mathrm{~nm}$ akan tertahan pada lapisan atas stratum korneum dan akan membentuk lapisan lipid pada kulit setelah mongering, sedangkan nanovesikel dengan ukuran partikel $\leq 300 \mathrm{~nm}$ dapat menghantarkan bahan aktif sampai ke lapisan kulit tertentu yang lebih dalam seperti epidermis dan dermis. ${ }^{14}$

\section{Indek Polidispersitas}

Hasil uji indeks polidispersitas menunjukkan bahwa ukuran partikel niosom pterostilben berdisitribusi homogen dengan nilai indeks polidispersitas (PDI) $<0,700$. Hasil uji ini ditunjukkan pada Tabel 3. Ditribusi ukuran partikel pada niosom pterostilben adalah homogen, yang ditunjukkan dengan nilai PDI yang berada pada rentang 0,260 - 0,470. Adanya proses pengecilan ukuran menggunakan ultra turrax dan sonikator dapat menghasilkan ukuran partikel dan nilai PDI yang lebih kecil. Metode hidrasi lapis tipis yang dikombinasi dengan metode pengecilan ukuran menggunakan sonikasi, terbukti dapat menurunkan nilai PDI yang tinggi. ${ }^{15}$

\section{Potensial Zeta}

Potensial zeta niosom pterostilben pada semua 
kelompok memiiki nilai negatif, namun tidak semua memenuhi rentang spesifikasi yang diinginkan, yaitu lebih dari +20 sampai dengan $+30 \mathrm{mV}$ dan lebih dari -20 sampai dengan $-30 \mathrm{mV}$. Nilai potensial zeta niosom pterostilben berada pada rentang $\pm 15-20 \mathrm{mV}$. Hasil pengukuran potensial zeta ditunjukkan pada Tabel 3. Pada hasil uji potensial zeta, diperoleh nilai potensial zeta niosom pterostilben dengan rentang -15 sampai dengan -22 mV. Nilai tersebut lebih rendah dari spesifikasi yang diinginkan. Pada umumnya, potensial zeta akan bernilai negative atau lebih rendah pada $\mathrm{pH}$ tinggi. $\mathrm{pH}$ merupakan salah satu faktor penting yang dapat mempengaruhi nilai potensial zeta. ${ }^{16}$ Nilai potensial zeta yang lebih rendah dari spesifikasi kemungkinan dikarenakan pada penelitian ini tidak digunakna bahan tambahan yang berfungsi untuk memodifikasi muatan energi suatu vesikel, seperti dicetylphosphate yang menginduksi muatan energi menjadi lebih negatif dan sterylamine yang menginduksi muatan energi menjadi lebih positif. Penambahan bahan penginduksi muatan dapat mencegah penggabungan vesikel dan meingkatkan nilai potensial zeta. ${ }^{17}$

Tabel 3.Hasil Karakterisasi Niosom Pterostilben

\begin{tabular}{|c|c|c|c|c|c|}
\hline \multirow{2}{*}{$\begin{array}{c}\text { Kelom } \\
\text { pok }\end{array}$} & \multirow{2}{*}{$\begin{array}{l}\text { Spesifi } \\
\text { kasi }\end{array}$} & \multicolumn{4}{|c|}{ Karakteristik } \\
\hline & & $\begin{array}{c}\mathrm{pH} \\
(\text { rata- } \\
\text { rata } \pm \text { SD) }\end{array}$ & $\begin{array}{c}\text { Ukuran } \\
\text { Partikel } \\
\text { (rata- } \\
\text { rata } \pm \text { SD) }\end{array}$ & $\begin{array}{c}\text { PDI } \\
\text { (rata- } \\
\text { rata } \pm S \\
D)\end{array}$ & $\begin{array}{c}\text { Potensial } \\
\text { Zeta } \\
\text { (rata- } \\
\text { rata } \pm \text { SD) }\end{array}$ \\
\hline K1 & \multirow{6}{*}{$\begin{array}{l}\mathrm{pH}= \\
5-8 \\
\text { Ukuran } \\
\text { Partike } \\
\mathrm{l}=51- \\
599 \mathrm{~nm} \\
\mathrm{PDI}= \\
0,05- \\
0,700\end{array}$} & 9 & $\begin{array}{c}304,4 \pm \\
1,99\end{array}$ & $\begin{array}{c}0,453 \pm \\
0,010\end{array}$ & $\begin{array}{c}22,8 \pm \\
1,3\end{array}$ \\
\hline K2 & & 9,204 & $\begin{array}{c}264,7 \pm \\
0,56\end{array}$ & $\begin{array}{c}0,424 \pm \\
0,024\end{array}$ & $\begin{array}{c}21,0 \pm \\
1,9\end{array}$ \\
\hline K3 & & 9,405 & $\begin{array}{c}276,97 \pm \\
3,37\end{array}$ & $\begin{array}{c}0,383 \pm \\
0,004\end{array}$ & $\begin{array}{c}15,0 \pm \\
1,3\end{array}$ \\
\hline F1 & & $\begin{array}{c}9,0633 \pm \\
0,2117\end{array}$ & $\begin{array}{c}317,51 \pm \\
6,59\end{array}$ & $\begin{array}{c}0,426 \pm \\
0,067\end{array}$ & $\begin{array}{c}20,9 \pm \\
2,3\end{array}$ \\
\hline F2 & & $\begin{array}{c}9,1597 \pm \\
0,1296\end{array}$ & $\begin{array}{c}281,17 \pm \\
19,71\end{array}$ & $\begin{array}{c}0,361 \pm \\
0,124\end{array}$ & $\begin{array}{c}21,6 \pm \\
1,6\end{array}$ \\
\hline F3 & & $\begin{array}{c}9,4610 \pm \\
0,0367\end{array}$ & $\begin{array}{c}235,25 \pm \\
6,88\end{array}$ & $\begin{array}{c}0,260 \pm \\
0,011\end{array}$ & $\begin{array}{c}18,0 \pm \\
0,76\end{array}$ \\
\hline
\end{tabular}

Keterangan: $\mathrm{K}=$ tanpa pterostilben, $\mathrm{F}=$ dengan pterostilben, $\mathrm{F} 1=$ konsentrasi Span $60400 \mathrm{mg}$, F2= konsentrasi Span $60400 \mathrm{mg}$, F3= konsentrasi Span $601200 \mathrm{mg}$.

\section{Uji Difusi in vitro}

Berdasarkan uji difusi yang dilakukan, diperoleh konsentrasi pterostilben yang terpentrasi setelah 2 jam adalah $175,44 \mathrm{ppm}$. Jumlah pterostilben yang terpentrasi adalah 1,74 mg. Hasil tersebut menunjukkan bahwa terjadi peningkatan konsentrasi pterostilben yang terpentrasi ke kompartemen donor seiring dengan bertambahnya waktu. Hasil uji difusi in vitro dapat dilihat pada Tabel 4. Berdasarkan hasil uji difusi in vitro niosom pterostilben, diperoleh jumlah pterostilben yang terpenetrasi setelah 2 jam adalah 1,74 mg. Jumlah tersebut kurang dari jumlah pterostilben yang seharusnya. Hal ini terjadi kemungkinan karena belum semua sampel terpentrasi setelah 2 jam, selain itu sampel yang berdifusi mungkin sebagian tertinggal dalam jaringan yang digunakan sebagai membran. ${ }^{18}$

Tabel 4. Hasil Uji Difusi In Vitro Franz Diffusion Cell Type

\begin{tabular}{lll}
\hline Waktu (menit) & Konsentrasi (ppm) & Pterostilben (mg)
\end{tabular}

\begin{tabular}{ccc}
\hline 15 & 89,8 & 0,81 \\
\hline 30 & 103,68 & 0,93 \\
\hline 45 & 138,31 & 1,24 \\
\hline 60 & 159,31 & 1,43 \\
\hline 90 & 175,44 & 1,58 \\
\hline 120 & 193,65 & 1,74 \\
\hline
\end{tabular}

\section{Daftar Pustaka}

1. Chen, Rong-Jane., Yu-Hsuan Lee., dkk. Autophagyinducing effect of pterostilben: A prospective therapeutic/preventive option for skin disease/ Journal of Food and Drug Analysis. 2017. 25: 125-133.

2. RISKESDAS (Riset Kesehatan Dasar). 2007. Jakarta: Badan Penelitian dan Pengembangan Kesehatan, Departemen Kesehatan Republik Indonesia.

3. Sirerol, J Antoni., Fatima Feddi., dkk. Topical treatment with pterostilben, a natural phytoalexin, effectively protects hairless mice against UVB radiation-induced skin damage and carcinogenesis. Free Radical Biology and Medicine. 2015. 85: $1-11$.

4. Ariquel, Jose Maria Estrela dan Miguel A. Asensi Miralles. 2013. Pterostilben (Pter) For Use in The Prevention and/or Treatment Skin Disease, Damage or Injuries. Patent Application Publication. United States

5. Karim, Kazi Masud., Asim Sattwa Mandal., dkk. Niosomes: a novel approach in modern drug delivery systems. Journal of Advanced Pharmaceutical Technology \& Research. 2016. 01(04): 374-380.

6. Tangri, Pranshu dan Saffi Khurna. Niosomes: Formulation and Evaluation. International Journal of Biopharmaceutics (IJB). 2011. 02(01): 47-53.

7. Shatalebi, M.A., S.A. Mostafavi., dan A. Moghaddas. Niosomes as a Drug Carrier for Topical Delivery N-acetyl Glucosamine. Research in Pharmaceutical Sciences. 2010. 5(2): 107-117.

8. Wardhani, Lilies Kusuma dan Nanik Sulistyani. Uji Aktifivtas Antibakteri Ekstrak Etil Asetat Daun BInahong (Andredera scandens (L.) Moq.) Terhadap Shigella flexneri Beserta Profil Kromatografi Lapis Tipis. Jurnal Ilmiah Kefarmasian. 2(1): 4-12.

9. Teselkin, Yu.O., dkk. Dihydroquercetin as a means of antioxidative defenc in rats with tetrachlormethane hepatitis. Phytotherapy Research. 2000. 14(3): 160-162.

10. Hamishehkar, Hamed., Yahya Rahimpour dan Maryam Kouhsoltani. Niosomes as a propitious carrier for topical drug delivery. Expert Opinion Drug Delivery. 2013. 10(2): 262.

11. Singh, S., S. Tivedi dan S. Jain. Design And Development of Proniosome Based Transdermal Delivery of Ondansentron Hydrochloride. International Journal of Pharmaceutical and Biological Research (IJBPR). 2012. 3(5): 191-195.

12. Budai, Livia., Nora Kaszas, Pal Grof, dkk. Liposomes for Topical Use: A Physico-Chemical Comparison of Vesicles Prepared from Egg or Soy Lecithin. Scientia Pharmaceutica. 2013. 81:1155.

13. ${ }^{1}$ Ali, Saba M. dan Gil Yosipovitch. Skin pH: Basic Science to Basic Skin Care. Acta Derm Venereol. 2013. 93: 93-261.

14. Danaei, M., M. Dehghankhold, S. Ataei, dkk. Impact of Particle Size and Polydispersity Index on the Clinical 
Applications of Lipidic Nanocarrier System. Journal Pharmaceutics. 2018. 10(57): 6-7.

15. Homaei, Maryam. 2016. Preparation and Characterization of Giant Niosomes. Master's Thesis in Nanotechnology. Departement of Microtechnology and Nanoscience Chalmers University of Technology, Gothenburg.

16. Key, Francis S. 2012. The Influence of $\mathrm{pH}$ on Zeta Potential. (Online). (http://www.silvercolloids.com/Tutorials/Intro/pcs18A.html. diakses pada 17 Juni 2019).

17. Sankhyan, Anehal dan Pravin Pawar. Recent Trends in NIosomes as Vesicular Drug Delivery System. Journal of Applied Pharamceutical Science. 2012. 02(06): 21.

18. Anggraeni, Y. 2013. Profil Difusi Natrium Diklofenak dari Sediaan Patch ke Gingiva Sapi. Lembaga Penelitian dan Pengembangan kepada Masyarakat UIN Syarif Hidayatullah Jakarta.

19. Alvi, Iqrar Ali., Jitender Madan, Dinesh Kaushik, dkk. Comparative study of transfersomes, liposomes, and niosomes for topical delivery of 5-fluorouracil to skin cancer cells: preparation, characterization, in-vitro release, and cytotoxicity analysis. Anti Cancer Drugs. 2010. 22(8): 774-772.

20. Manconi M., Valenti D, Sinico C, dkk. Niosomes as carriers for tretinoin: II. Influence of vesicular incorporation on tretinoin photostability. International Journal Pharm. 2003. 260 (2): 261.

21. Zhang, Yue., Zhenhua Shang, Chunhui Gao, dkk. Nanoemulsion for Solubilization, Stabilization, and In Vitro Release of Pterostilben for Oral Delivery. American Association of Pharmaceutical Scientists (AAPS PharmSciTech). 2014. Vol 15(4): 1000-1001.

22. Debnath, Arunima dan Anup Kumar. Structural and Functional significance of Niosome and Proniosome in Drug Delivery System. International Journal of Pharmacy and Engineering (IJPE). 2015. 03 (03): 621 - 637.

23. Yeo, Li Key., Cheng Shu Chaw dan Amal Ali Elkorday. The effects of Hydration Parameters and Co-Surfactants on Methylene Blue-Loaded Niosomes Prepared by the Thin Film Hydration Method. Pharmaceuticals. 2019. 12(46): 4.

24. SNI 16-4399-1996.(1996). Sediaan Tabir Surya. Badan Standarisasi Nasional. Jakarta.

25. Khoee, Sepideh., dan Yaghoobian, Morteza. Niosomes : a novel approach in modern drug delivery systems. Science Direct. 2017.

26. Yadav, Kiran., Deepak Yadav., Kamal Saroha., dkk. Proniosomal Gel: A provesicular approach for transdermal drug delivery. Scholars Research Library. 2010. 2(4). 189198.

27. Desnita, Rise., Lestiawati, Veni., dan Apridamayanti, Pratiwi. 2015. Penggunaan Span-40 sebagai Penyusun Niosom Natrium Askorbil Fosfat dalam Sediaan Gel terhadap Penetrasinya secara in vitro. Naskah Publikasi. Fakultas Kedokteran Universitas Tanjungpura. Pontianak. 